\title{
Effects of pressure-support ventilation with different levels of positive end-expiratory in a mild model of acute respiratory distress syndrome
}

\author{
PAF Magalhães ${ }^{1,2 *}$, GDA Padilha', L Moraes ${ }^{1}$, CL Santos $^{1}$, LB de Andrade ${ }^{2}$, MGPdA Magalhães ${ }^{2}$, MDCMB Duarte ${ }^{2}$, \\ PRM Rocco ${ }^{1}$, PL Silva ${ }^{1}$
}

From ESICM LIVES 2015

Berlin, Germany. 3-7 October 2015

\section{Introduction}

Pressure-support ventilation improves lung mechanics, blood gas exchange, hemodynamics, and work of breathing (WOB) in mild acute respiratory distress syndrome (ARDS) [1,2]. Nevertheless, those beneficial effects could be dependent of positive end-expiratory pressure (PEEP) applied during mechanical ventilation. So far, no study has compared pressure-support ventilation (PSV) with pressure controlled ventilation (PCV) in different PEEP levels.

\section{Objective}

To compare PSV and PCV target to protective tidal volume $\left(\mathrm{V}_{\mathrm{T}}=6 \mathrm{ml} / \mathrm{kg}\right)$ using two PEEP levels ( 2 and 5 $\mathrm{cmH}_{2} \mathrm{O}$ ) in a mild ARDS model.

\section{Methods}

Thirty-two male Wistar rats $(310 \pm 19 \mathrm{~g})$ were submitted to intratracheal Escherichia coli lipopolysaccharide $(200 \mu \mathrm{g}$ in $200 \mu \mathrm{l}$ of saline) instillation. After 24 hours, animals were anesthetized, tracheotomized, and their lungs were mechanically ventilated in PSV to achieve $V_{T}=6 \mathrm{ml} / \mathrm{kg}$. After baseline data collection, animals were randomly divided to four groups ( $\mathrm{n}=8$ /group):

1) $\mathrm{PCV}+\mathrm{PEEP}=2 \mathrm{cmH}_{2} \mathrm{O}(\mathrm{PCV}-\mathrm{P} 2)$;

2) $\mathrm{PCV}+\mathrm{PEEP}=5 \mathrm{cmH}_{2} \mathrm{O}(\mathrm{PCV}-\mathrm{P} 5)$;

3) $\mathrm{PSV}+\mathrm{PEEP}=2 \mathrm{cmH}_{2} \mathrm{O}$ (PSV-P2);

4) $\mathrm{PSV}+\mathrm{PEEP}=5 \mathrm{cmH}_{2} \mathrm{O}$ (PSV-P5).

Animals were ventilated for 2 hours. Mean arterial pressure (MAP), arterial blood gases, peak airway (Ppeak, RS) and peak transpulmonary (Ppeak, ${ }_{\mathrm{L}}$ ) pressures, and pressure-time product (PTP), as a surrogate of WOB, were evaluated.

\section{Results}

All animals showed better oxygenation along time, regardless of ventilator strategy. Animals submitted to PCV, regardless of PEEP, received more colloids to keep $\mathrm{MAP}>70 \mathrm{mmHg}$. Ppeak, ${ }_{\mathrm{RS}}$, and Ppeak, ${ }_{\mathrm{L}}$ were higher in animals submitted to PEEP $=5 \mathrm{cmH}_{2} \mathrm{O}$ than PEEP $=2$ $\mathrm{cmH}_{2} \mathrm{O}$, independently of pressure-controlled, and pressure-support ventilator strategies. Nevertheless, at PEEP = $5 \mathrm{cmH}_{2} \mathrm{O}$, but not at PEEP $=2 \mathrm{cmH}_{2} \mathrm{O}$, animals submitted to PSV showed lower Ppeak, ${ }_{\mathrm{RS}}$, and Ppeak, $\mathrm{L}_{\mathrm{L}}$ compared to PCV animals (PSV-P5:11.2 $\pm 1.9 \mathrm{cmH}_{2} \mathrm{O}$ vs PCV-P5:15.3 $\left.\pm 1.4 \mathrm{cmH}_{2} \mathrm{O}, \mathrm{p}<0.05\right)$. In accordance, PTP was lower in animals submitted to PEEP $=5 \mathrm{cmH}_{2} \mathrm{O}$ compared to PEEP $=2 \mathrm{cmH}_{2} \mathrm{O}$ during PSV (PSV-P5:0.08 \pm 0.03 $\mathrm{cmH}_{2} \mathrm{O} . \mathrm{s}$ vs PSV-P2:0.22 $\left.\pm 0.09 \mathrm{cmH}_{2} \mathrm{O} . \mathrm{s}, \mathrm{p}<0.05\right)$.

\section{Conclusion}

In a mild ARDS model, pressure-support ventilation is associated to better hemodynamics, lung mechanics, and it seems to have a dependent effect of the adjusted PEEP level, as depicted by work of breathing.

\section{Grant Acknowledgment \\ CNPq, FAPERJ, CAPES, PRONEX, MS-DECIT}

\section{Authors' details}

${ }^{1}$ Federal University of Rio de Janeiro, Rio de Janeiro, Brazil. ${ }^{2}$ Professor Fernando Figueira Mother and Child Institute, Recife, Brazil. 


\section{References}

1. Guldner A, Pelosi P, Gama de Abreu M: Spontaneous breathing in mild and moderate versus severe acute respiratory distress syndrome. Curr Opin Crit Care 2014, 20(1):69-76.

2. Grinnan DC, Truwit JD: Clinical review: Respiratory mechanics in spontaneous and assisted ventilation. Crit Care 2005, 9(5):472-484.

doi:10.1186/2197-425X-3-S1-A573

Cite this article as: Magalhães et al:: Effects of pressure-support

ventilation with different levels of positive end-expiratory in a mild model of acute respiratory distress syndrome. Intensive Care Medicine Experimental 2015 3(Suppl 1):A573.

\section{Submit your manuscript to a SpringerOpen ${ }^{\mathcal{O}}$ journal and benefit from:}

- Convenient online submission

- Rigorous peer review

- Immediate publication on acceptance

- Open access: articles freely available online

- High visibility within the field

- Retaining the copyright to your article

Submit your next manuscript at $\gg$ springeropen.com 